\title{
FETAL AND INFANT MORTALITY ASSOCIATED WITH CONGENITAL MALFORMATIONS
}

\author{
I. D. GERALD RICHARDS* \\ Department of Social and Occupational Medicine, Welsh National School of Medicine, Cardiff
}

With the decline in mortality from other causes, relating to all births in the survey years was congenital malformations represent an increasingly important cause of stillbirth and infant death. Malformations are also an important cause of spontaneous abortion and this paper examines the high fetal and infant loss associated with these conditions, using data collected on all births in 1964-66 to women resident in South Wales. The birth population and the ascertainment methods used in the survey have been described elsewhere (Richards and Lowe, 1971). Information on maternal age, parity, previous abortions, and parental occupation abstracted from birth notification forms on to coding cards for punching and analysis. The Registrar General of England and Wales supplied photocopies of the registrations of all stillbirths and infant deaths occurring in South Wales among infants born in the three years of the survey; while it is possible that some deaths occurred outside the survey area, their number is likely to be so small as to have a negligible effect on the infant mortality rates reported here.

TABLE I

ABORTIONS AMONG PREVIOUS PREGNANCIES ACCORDING TO TYPE OF MALFORMATION

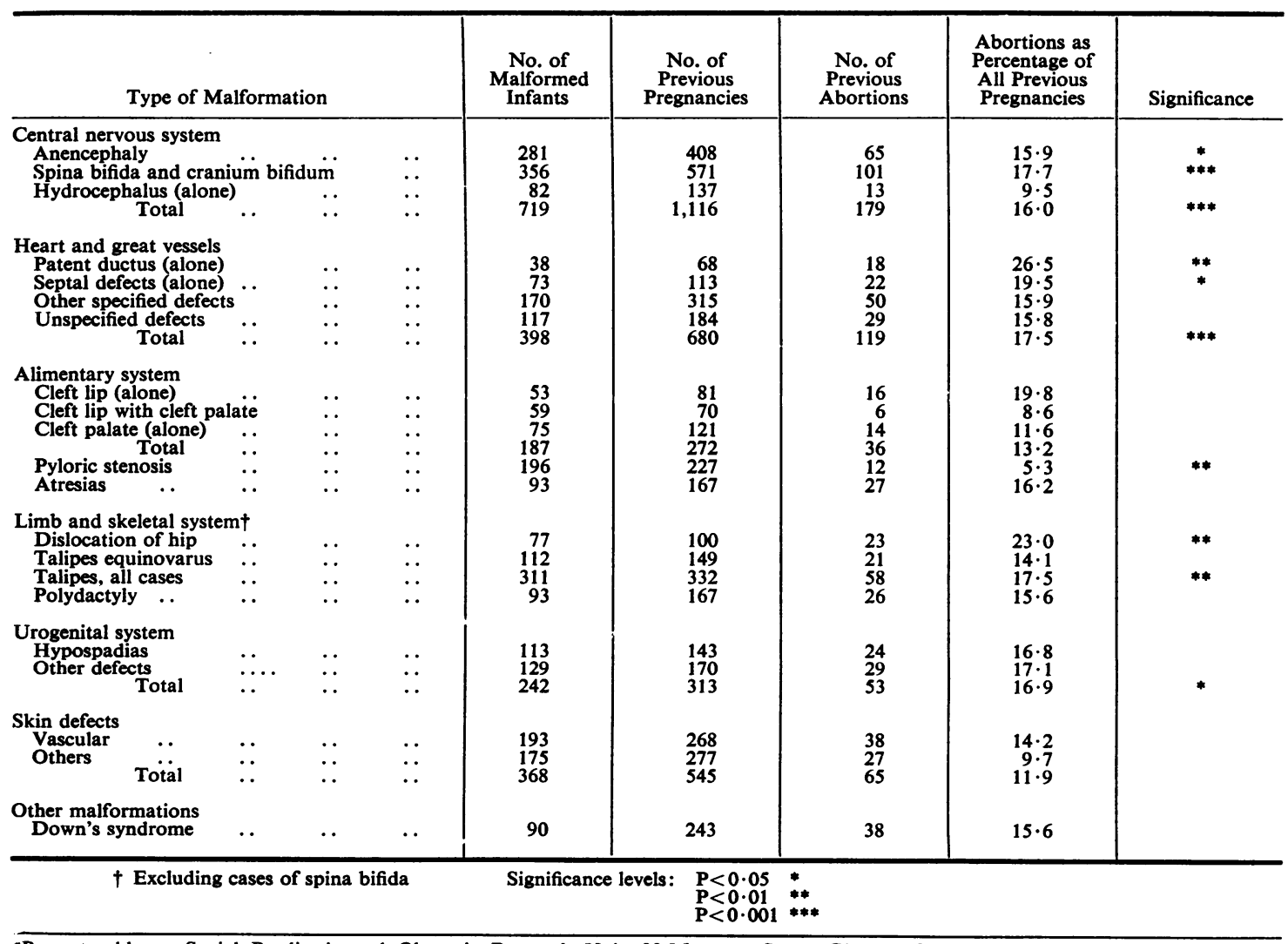


TABLE II

MALFORMATION RATES RELATED TO PARITY AND PREVIOUS ABORTIONS

\begin{tabular}{|c|c|c|c|c|c|c|c|c|c|}
\hline & & & & \multirow{2}{*}{$\begin{array}{c}\text { No. of } \\
\text { Previous } \\
\text { Abortions }\end{array}$} & \multicolumn{5}{|c|}{ Maternal Parity } \\
\hline & & & & & $\mathbf{0}$ & \multicolumn{2}{|c|}{1} & 2 and over & Total \\
\hline No. of births $\ldots$ & $\cdots$ & & .. & $\begin{array}{c}0 \\
1 \\
2 \\
3 \\
\text { Total }\end{array}$ & $\begin{array}{r}29,774 \\
1,879 \\
295 \\
102 \\
32,050\end{array}$ & \multicolumn{2}{|c|}{$\begin{array}{r}23,685 \\
2,605 \\
553 \\
202 \\
27,045\end{array}$} & $\begin{array}{r}24,714 \\
4,778 \\
1,076 \\
539 \\
31,107\end{array}$ & $\begin{array}{r}78,173 \\
9,262 \\
1,924 \\
843 \\
90,202\end{array}$ \\
\hline All malformations* & .. & .. & . & $\begin{array}{c}0 \\
1 \\
2 \\
3 \\
\text { Total }\end{array}$ & $\begin{array}{rr}3.9 & (1,161) \\
4.8 & (90) \\
5.4 & (16) \\
11.8 & (12) \\
4.0 & (1,279)\end{array}$ & $\begin{array}{l}3 \cdot 1 \\
4 \cdot 0 \\
4 \cdot 9 \\
4 \cdot 5 \\
3 \cdot 2\end{array}$ & $\begin{array}{r}(734) \\
(104) \\
(27) \\
(9) \\
(874)\end{array}$ & $\begin{array}{rr}3 \cdot 2 & (791) \\
4 \cdot 5 & (215) \\
4 \cdot 3 & (46) \\
3 \cdot 7 & (20) \\
3 \cdot 4 & (1,072)\end{array}$ & $\begin{array}{rr}3.4 & (2,686) \\
4.4 & (409) \\
4.6 & (89) \\
4.9 & (41) \\
3.6 & (3,225)\end{array}$ \\
\hline \multicolumn{4}{|c|}{ Malformations of central nervous system* } & $\begin{array}{c}0 \\
1 \\
2 \\
3 \\
\text { Total }\end{array}$ & $\begin{array}{rr}1.0 & (303) \\
0.8 & (15) \\
1.7 & (5) \\
4.9 & (5) \\
1.0 & (328)\end{array}$ & $\begin{array}{l}0.6 \\
0.7 \\
1.6 \\
1.0 \\
0.6\end{array}$ & $\begin{array}{r}(134) \\
(17) \\
(9) \\
(2) \\
(162)\end{array}$ & $\begin{array}{rr}0.7 & (162) \\
1.0 & (46) \\
1.3 & (14) \\
1.3 & (7) \\
0.7 & (229)\end{array}$ & $\begin{array}{lr}0.8 & (599) \\
0.8 & (78) \\
1.5 & (28) \\
1.7 & (14) \\
0.8 & (719)\end{array}$ \\
\hline \multicolumn{4}{|c|}{ Malformations of heart and great vessels* } & $\begin{array}{c}0 \\
1 \\
2 \\
3 \\
\text { Total }\end{array}$ & $\begin{array}{lr}0.3 & (96) \\
0.5 & (10) \\
1.0 & (3) \\
2.9 & (3) \\
0.4 & (112)\end{array}$ & $\begin{array}{l}0.3 \\
0.4 \\
0.5 \\
1.0 \\
0.4\end{array}$ & $\begin{array}{r}(80) \\
(11) \\
(3) \\
(2) \\
(96)\end{array}$ & $\begin{array}{lr}0.4 & (105) \\
0.8 & (36) \\
0.7 & (7) \\
0.9 & (5) \\
0.5 & (153)\end{array}$ & $\begin{array}{l}(281) \\
(57) \\
(13) \\
(10) \\
(361)\end{array}$ \\
\hline
\end{tabular}

* Rates are expressed per 100 related births; malformed infants are shown in parentheses

TABLE III

STILLBIRTHS AND INFANT DEATHS AMONG MALFORMED SINGLETON BIRTHS

\begin{tabular}{|c|c|c|c|c|c|c|c|c|}
\hline \multirow{2}{*}{\multicolumn{4}{|c|}{ Type of Malformation }} & \multirow{2}{*}{$\begin{array}{c}\text { No. of } \\
\text { Malformed } \\
\text { Infants }\end{array}$} & \multicolumn{3}{|c|}{ Cumulative Deaths } & \multirow{2}{*}{$\begin{array}{c}\text { Mortality at } \\
1 \text { year as } \\
\text { percent of } \\
\text { All Cases }\end{array}$} \\
\hline & & & & & Stillborn & At 1 week & At 1 year & \\
\hline \multicolumn{3}{|c|}{ 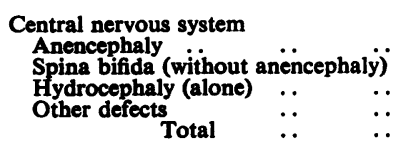 } & $\begin{array}{l}\ddot{.} \\
\ddot{0} \\
.\end{array}$ & $\begin{array}{r}281 \\
331 \\
82 \\
49 \\
743\end{array}$ & $\begin{array}{r}260 \\
72 \\
44 \\
9 \\
385\end{array}$ & $\begin{array}{r}281 \\
126 \\
49 \\
9 \\
465\end{array}$ & $\begin{array}{r}281 \\
194 \\
57 \\
21 \\
553\end{array}$ & $\begin{array}{r}100 \\
59 \\
70 \\
43 \\
74\end{array}$ \\
\hline $\begin{array}{c}\text { Heart and great vessels } \\
\text { Patent ductus (aione) } \\
\text { Septal defects (ajone) } \\
\text { Transposition of great } \\
\text { Coarctation of aorta } \\
\text { Fallot's tetrad. } \\
\text { Other specified defects } \\
\text { Unspecified defects } \\
\text { Total }\end{array}$ & $\begin{array}{c}\because \\
\text { vesse } \\
\ddot{ } \\
\because \\
\because \\
\because\end{array}$ & $\begin{array}{l}\because \\
\because \\
\because \\
\because \\
\because\end{array}$ & $\begin{array}{l}. \\
\because \\
\ddot{ } \\
\because \\
\because \\
.\end{array}$ & $\begin{array}{r}38 \\
73 \\
34 \\
30 \\
16 \\
90 \\
117 \\
398\end{array}$ & $\begin{array}{l}0 \\
5 \\
0 \\
1 \\
0 \\
1 \\
1 \\
8\end{array}$ & $\begin{array}{l}11 \\
16 \\
1 \\
12 \\
2 \\
24 \\
10 \\
76\end{array}$ & $\begin{array}{r}16 \\
30 \\
24 \\
30 \\
8 \\
53 \\
27 \\
188\end{array}$ & $\begin{array}{r}42 \\
41 \\
71 \\
100 \\
50 \\
59 \\
23 \\
47\end{array}$ \\
\hline $\begin{array}{l}\text { Alimentary system } \\
\text { Cleft lip and/or palate } \\
\text { Pyloric stenosis } \\
\text { Atresia_-oesophageal } \\
\text {-intestinal } \\
\text {-anorectal }\end{array}$ & $\begin{array}{l}\because \\
\because \\
\because \\
.\end{array}$ & $\begin{array}{l}\because \\
\because \\
\because\end{array}$ & $\begin{array}{l}. \\
\because \\
\because \\
\because\end{array}$ & $\begin{array}{r}187 \\
196 \\
37 \\
21 \\
37\end{array}$ & $\begin{array}{r}11 \\
0 \\
0 \\
1 \\
0\end{array}$ & $\begin{array}{r}19 \\
0 \\
6 \\
4 \\
8\end{array}$ & $\begin{array}{c}21 \\
4 \\
14 \\
7 \\
15\end{array}$ & $\begin{array}{l}11 \\
2 \\
38 \\
33 \\
41\end{array}$ \\
\hline $\begin{array}{l}\text { Other systems } \\
\text { Talipes } \\
\text { Hypospadias } \because \ddot{~} \\
\text { Other urogenitai } \\
\text { Down's syndrome }\end{array}$ & $\begin{array}{l}.: \\
\because .\end{array}$ & $\begin{array}{l}\because \\
\because \\
.\end{array}$ & $\begin{array}{l}\ddot{ } \\
\ddot{.}\end{array}$ & $\begin{array}{l}311 \\
113 \\
129 \\
90\end{array}$ & $\begin{array}{l}7 \\
0 \\
8 \\
5\end{array}$ & $\begin{array}{r}10 \\
2 \\
33 \\
14\end{array}$ & $\begin{array}{r}14 \\
4 \\
48 \\
30\end{array}$ & $\begin{array}{r}5 \\
4 \\
37 \\
33\end{array}$ \\
\hline
\end{tabular}




\section{RESULTS}

\section{Abortions among Earlier Pregnancies}

The analysis has been confined to singleton births, of which there were 90,921 in the three years of the investigation. Data regarding a history of previous abortion are complete for 90,202 births. Of the 134,289 earlier pregnancies recorded in these women, $15,639(11 \cdot 6 \%)$ terminated in abortion. Congenital malformations were reported in 3,242 singleton infants and data on previous abortions are complete for 3,225 of them.

In Table $I$, the incidence of abortion among previous pregnancies (for each type of malformation) is compared with the rate recorded for all births $(11.6 \%)$. Abortion rates were significantly raised in malformations of the central nervous system and of the heart and great vessels. Several individual malformations also had increased rates, viz., anencephaly, spina bifida, patent ductus, septal defects, dislocation of hip, talipes, and urogenital defects (excluding hypospadias). In pyloric stenosis the rate was significantly lower than expected.

Table II shows how the incidence of all malformations combined varied with maternal parity and with the number of previous abortions. Malformation incidence was lowest (at all parities) in the absence of a previous history of abortion. In primiparous births, incidence rose with increase in the number of previous abortions, being particularly high $(11.8 \%)$ after three abortions There was a similar pattern in malformations of the central nervous system and of the heart and great vessels.

\section{Stillbirths ANd INFANT Deaths}

The cumulative mortality up to 1 year is shown in Table III.

\section{Malformations of the Central Nervous System} There were 743 infants with defects of the central nervous system; 281 had anencephaly with or without spina bifida, and 331 had spina bifida without anencephaly.

Anencephaly Ninety-three per cent of anencephalics were stillborn and mortality was complete within four days of birth.

Spina bifida (excluding anencephaly and encephalocoele) Twenty-two per cent were stillborn and mortality had reached $59 \%$ by the first anniversary of birth.

Some of the important determinants of spina bifida mortality are examined in Table IV. It was higher in females $(64 \%)$ than in males $(51 \%)$. At birth weights below $4 \mathrm{lb}$. no infants survived; between $4 \mathrm{lb}$ and $5 \mathrm{lb} 15 \mathrm{oz}$ the mortality rate $(63 \%)$ was appreciably greater than at higher weights $(51 \%)$.

An associated hydrocephalus increased the mortality from $39 \%$ to $76 \%$. Mortality varied
TABLE IV

MORTALITY IN SPINA BIFIDA

(EXCLUDING ANENCEPHALY AND ENCEPHALOCOELE)

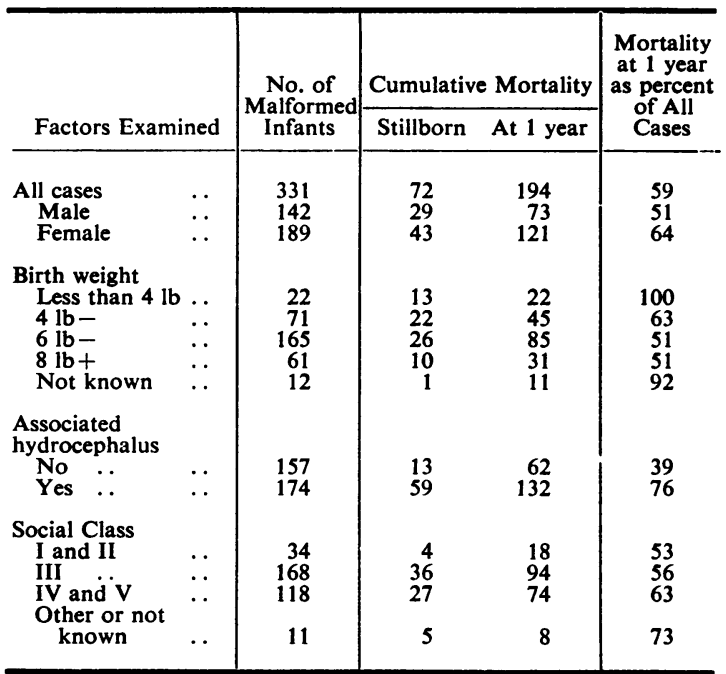

according to social class, rising from $53 \%$ in social classes I and II to $63 \%$ in classes IV and V.

Other malformations Fifty-four per cent of cases of congenital primary hydrocephalus were stillborn and mortality by 1 year was $70 \%$. Of 25 infants with encephalocoele, 8 were stillborn and 13 died in infancy; of 13 infants with microcephalus, one was stillborn and four died in infancy.

Malformations of the Heart and Great VESSELS Including cases of Down's syndrome, there were in the series 398 infants with cardiovascular defects, of whom 8 were stillborn, 68 died in the first week of life, and a further 112 died in the remainder of the first year. Mortality at 1 year was $47 \%$.

Among specified defects, mortality ranged from $41 \%$ in septal defects (without other cardiovascular defects) to $100 \%$ in coarctation of the aorta. Mortality in unspecified defects was much lower $(23 \%)$.

Malformations of the Alimentary System Mortality in infants with clefts of the lip and/or palate was $11 \%$ and with pyloric stenosis $2 \%$. Of the 37 infants with oesophageal atresia 14 died in infancy, 8 of the deaths being in infants with an associated cardiac malformation. Intestinal atresia had a similar mortality; of 21 cases, one was stillborn and six died in infancy, one death being associated with a cardiac malformation. Of the 37 infants with anorectal atresia 15 died in infancy, four being associated with a cardiac defect. 
Miscellaneous Malformations Mortality among 311 infants with talipes (not associated with spina bifida) was $5 \%$. There was also low mortality in hypospadias (4\%) although a much higher rate in other urogenital defects $(37 \%), 16$ of the 48 deaths being in infants with associated malformations (congenital heart disease or intestinal atresia).

TABLE V

MORTALITY IN DOWN'S SYNDROME

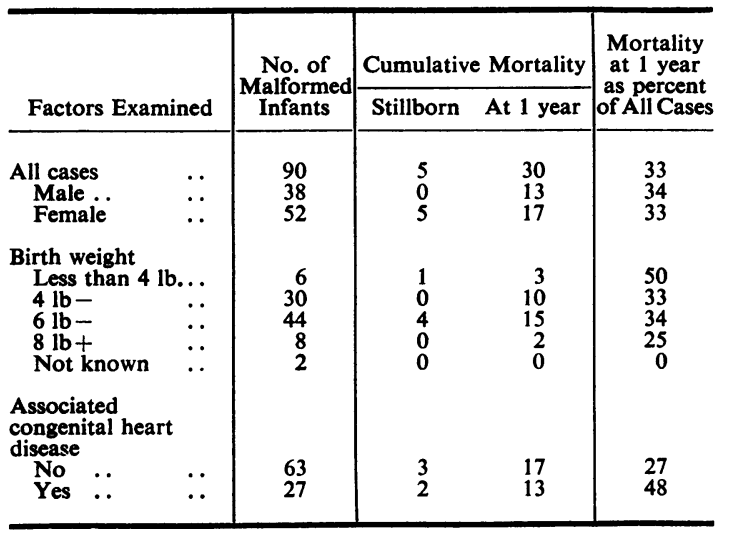

Of 90 infants with Down's syndrome, 5 were stillborn and 25 died in infancy, the cumulative mortality at 1 year being $33 \%$. There was no sex difference in mortality but low birth weight appears to have an important influence on mortality (Table V). At weights under $4 \mathrm{lb}$ mortality was $50 \%$ but decreased to $25 \%$ at weights of $8 \mathrm{lb}$ and over. Mortality was high (48\%) in cases with a reported cardiac defect, although it is possible that here, as with other malformations, the existence of the associated defect was discovered (or reported) only as a result of necropsy examination.

\section{Discussion}

The prevalence of malformations at birth depends on (1) the incidence at conception, and (2) the loss of malformed embryos or fetuses early in pregnancy (before the 28th week). For this reason, a history of previous abortions in relation to the prevalence at birth of malformation is of great interest. Raised abortion rates have been recorded for mothers of children with malformations of the central nervous system (Malpas, 1937; Böök and Rayner, 1950; Record and McKeown, 1950; Smithells, Chinn and Franklin, 1964; Smithells and Chinn, 1965; Richards, McIntosh, and Sweenie, 1972). Although these reports are based on retrospective enquiries (with the well-recognized bias that women who have given birth to malformed infants are more likely to remember and report previous abortions than women who have normal infants), they are very suggestive of increased fetal loss in these families. In the present study, total malformations of the central nervous system and cardiovascular system were associated with a raised abortion rate among previous pregnancies, as were several individual malformations; malformation prevalence at birth was found to rise with an increase in the number of previous abortions.

A very high frequency of malformations is found among spontaneously aborted fetuses (Warburton and Fraser, 1959; Hayashi, 1961) and there is evidence that a high proportion of malformed fetuses are lost by spontaneous abortion (Nishimura, 1970). For several malformations, there is an increased risk of recurrence after the birth of an affected child (Blyth and Carter, 1969) and Richards, McIntosh, and Sweenie (1972) found that in mothers giving birth to infants with anencephaly or spina bifida, $41 \%$ of all known pregnancies ended in either abortion or the birth of a child with a congenital defect.

Having found asymmetries in family structure $\vec{\varphi}$ for Down's syndrome, congenital heart disease c. pyloric stenosis, and oral clefts, Knox (1963 suggested that the determinants of many malforo mations are associated with lethal effects affecting family fertility, in many instances sex-biased, and that in all likelihood 'failure to be born is at least as frequent a manifestation of these determinants as is the malformation itself'. It seems reasonable to postulate that in the present study much of the fetal loss among earlier pregnancies was due to malformation.

Congenital malformations are also an important cause of stillbirth and of death in infancy and early childhood. McKeown and Record (1960) found that only half of the malformed liveborn children in their Birmingham study were alive at age 5 compared with $95 \%$ of those not malformed. In the present series, mortality (by the first anniversary of birth) was greatest among infants with malformations of the central nervous system $(74 \%)$, malformations of the heart and great vessels (47\%), anorectal atresia (41\%), and oesophageal atresia (38\%).

Mortality in malformed infants is related to several factors:

(a) Sex of infant: For two malformations, higher death rates have been reported among females, viz., spina bifida (Doran and Guthkelch, 1961 ; Laurence and Tew, 1971; Wilson, 1970) and Down's syndrome (Penrose, 1932; Øster, 1953; Record and Smith, 1955; Carter, 1958; Cowie, 1970). In the present 
study, mortality in spina bifida was highest among females, but there was no sex difference in mortality in Down's syndrome.

(b) Birth weight: Mortality in spina bifida and in Down's syndrome is closely related to birth weight in this series; a similar association has been reported by Cozzi and Wilkinson (1968) for anorectal anomalies.

(c) Associated defects: Mortality is considerably increased where there is more than one malformation present (McKeown and Record, 1960). This increased risk is seen in the present series when spina bifida is accompanied by hydrocephalus, Down's syndrome by congenital heart disease, alimentary tract atresia by congenital heart disease, and defects of the urogenital tract (excluding hypospadias) by congenital heart disease or intestinal atresia.

(d) Treatment: In this study no attempt was made to relate mortality and survival to the type of treatment given to the infant. However, it is known that surgical treatment of spina bifida and its complications was increasing during the survey years. The effect of improved care is seen in the fall in mortality since an earlier study in South Wales when the cumulative mortality at 1 year among spina bifida births in 1956-62 was $82 \%$ (Laurence and Tew, 1971).

\section{SUMmaRY}

Using data from the South Wales Survey of Congenital Malformations, it was found that malformations of the central nervous system and the cardiovascular system were associated with significantly raised abortion rates among previous pregnancies, as also were several individual malformations. Malformation prevalence at birth was shown to rise with an increase in the number of previous abortions; this trend was very marked in primiparous births.

Cumulative mortality rates at the first anniversary of birth are presented and the disadvantageous effects of low birth weight and of the presence of associated defects are clearly illustrated.

I acknowledge with gratitude the generous grant from the Association for the Aid of Crippled Children, New York, which made this investigation possible. It is with pleasure that I acknowledge my indebtedness to the Medical Officers of Health of Cardiff, Merthyr Tydfil, Swansea, Glamorgan, and Monmouthshire for their interest and co-operation, and to the many hospital consultants and medical records officers who notified the names of children with congenital defects. I am indebted also to the Registrar General for supplying photocopies of stillbirth and infant death registrations, to Mrs. S.
Lloyd for programming the material for computerization, and to Dr. J. Howlett and Mrs. J. Lay of the Atlas Computer Laboratory, Chilton for their help. Lastly, I express my gratitude to Professor C. R. Lowe for his valuable guidance and criticism throughout this study, to Mrs. S. Sweenie for statistical assistance, and to Miss M. Tinning for much clerical help.

\section{REFERENCES}

Blyth, Helen, and Carter, C. O. (1969). A guide to genetic prognosis in paediatrics. Develop. Med. Child Neurol., 11, Suppl. 18.

Böök, J. A. and RAYNer, S. (1950). A clinical and genetical study of anencephaly. Amer. J. hum. Genet., 2, 61.

CArter, C. O. (1958). A life table for mongols with the causes of death. J. ment. Defic. Res., 2, 64 .

COWIE, VALERIE A. (1970). A Study of the Early Development of Mongols. Permagon Press, Oxford.

CozzI, F., and Wilkinson, A. W. (1968). Congenital abnormalities of anus and rectum: mortality and function. Brit. med. J., 1, 144.

Doran, P. A., and Guthkelch, A. N. (1961). Studies in spina bifida cystica. I. General survey and reassessment of the problem. J. Neurol. Neurosurg. Psychiat., 24, 331.

HAYASHI, I. (1961) Etiology of malformations (in Japanese). Iga Kunoamyumi, 37, 74.

KNox, E. G. (1963). The family characteristics of children with clefts of lip and palate. Acta genet. (Basel), 13, 299.

(1967). Spina bifida in Birmingham. Develop. Med. Child Neurol., 9, Suppl. 13, p. 14.

LAURENCE, K. M., and Tew, B. J. (1971). Natural history of spina bifida cystica and cranium bifidum cysticum. Arch. Dis. Childh., 46, 127.

McKeown, T., and Record, R. G. (1960). Malformation in a population observed for five years after birth. In Ciba Foundation Symposium on Congenital Malformations, edited by G. E. W. Wolstenholme and C. M. O’Connor, pp. 2-21. Churchill, London.

MALPAS, P. (1937). The incidence of human malformations. J. Obstet. Gynaec. Brit. Emp., 44, 434.

NishimurA, H. (1970). Incidence of malformations in abortions. In Congenital Malformations, Proceedings of the Third International Conference, the Hague, the Netherlands, 7-13 September 1969. p. 275 edited by F. C. Fraser and V. A. McKusick. Excerpta Medica, Amsterdam.

ØSTER, J. (1953). Mongolism. A Clinicogenealogical Investigation Comprising 526 Mongols living on Zeeland and Neighbouring Islands in Denmark. Danish Science Press, Copenhagen. 
Penrose, L. S. (1932). On interaction of heredity and environment in a study of human genetics with special reference to mongolian imbecility. J. Genet., 25, 407.

ReCoRD, R. G., and McKeown, T. (1950). Congenital malformations of the central nervous system. II. Maternal reproductive history and familial incidence. Brit. J. prev. soc. Med., 4, 26.

—, and SмIтH, A. (1955). Incidence, mortality, and sex distribution of mongoloid defectives. Brit. J. prev. soc. Med., 9, 10.

RichaRDS, I. D. G., and LowE, C. R. (1971). Incidence of congenital defects in South Wales, 1964-66. Brit. J. prev. soc. Med., 25, 59.
—, McIntosh, H. T., and Sweenie, S. (1972). A genetic study of anencephaly and spina bifida in Glasgow. Develop. Med. Child Neurol., 14, 626.

Smithells, R. W., and ChINN, E. R. (1965). Spina bifida in Liverpool. Develop. Med. Child Neurol., 7, 258.

- , and Franklin, D. (1964). Anencephaly in Liverpool. Develop. Med. Child Neurol., 6, 231.

Warburton, D., and Fraser, F. C. (1959). Genetic $\frac{\overrightarrow{\mathbb{D}}}{\mathrm{d}}$ aspects of abortion. Clin. Obstet. Gynec., 2, 22.

WiLson, T. S. (1970). Congenital malformations of the central nervous system among Glasgow births 1964-68. $\overrightarrow{0}$ Hlth Bull., (Edinb.), 28, No. 4, 32. 